\title{
Influences of Climate and Agriculture on Water and Biogeochemical Cycles: Kabini Critical Zone Observatory
}

\author{
M SEKHAR $^{1,2, *}$, J RIOTTE ${ }^{2,3}$, L RUIZ $^{2,4}$, P JOUQUET ${ }^{2,5}$ and J J BRAUN ${ }^{3}$ \\ ${ }^{1}$ Indian Institute of Science, 560012 Bangalore, India \\ ${ }^{2}$ Indo-French Cell for Water Sciences, Indian Institute of Science, Bangalore, India \\ ${ }^{3}$ IRD, GET UMR 5563 (Univ. Toulouse, CNRS, IRD), 31400 Toulouse, France \\ ${ }^{4} I N R A, U M R 1069$ SAS, 35000 Rennes, France \\ 5IRD, iEES, 93143 Bondy, France
}

(Received on 30 April 2016; Accepted on 25 May 2016)

\begin{abstract}
In the last decades, globally several small experimental watersheds were set up to study the climate and agricultural influences on water and biogeochemical cycles. Recently, the concept and importance of Critical Zone Observatory (CZO) was made and this resulted in developing such observatories in several countries including a global network of CZOs. The CZOs combine characterization, long term monitoring and modeling to allow understanding of the processes governing water and biogeochemical cycles in a small experimental watershed or network of watersheds. The Kabini CZO too was formed from similar twin experimental watersheds (forested and cultivated) developed during the last decade in the Kabini river basin in the south western part of India. A summary of the salient studies performed on water and biogeochemical cycles under the influence of climate and agriculture during the last ten years in the Kabini CZO are reported here.
\end{abstract}

Keywords: Critical Zone Observatory, CZO, Small Experimental Watershed, Hydrology, Biogeochemistry.

\section{Introduction}

The Earth Critical Zone is defined as "the thin layer between the top of the canopy and the bottom of groundwater aquifer in which complex interactions involving rock, soil water, air and living organisms regulate the natural habitat and determine availability of life sustaining resources" (NRC report, 2001). Critical Zone Observatories (CZOs) have been implemented by the Earth Science community in the past 25 years in several countries (Banwart et al. 2013) with an aim to answer crucial environmental questions such as:

- What is the impact of land-use changes on the hydrological and biogeochemical fluxes exported from watersheds?

- How climate variability controls the processes involved in water-soil-life interactions?

- What is the control of biosphere on the hydrological and biogeochemical cycles in the different continental ecosystems at seasonal, yearly, decennial, and multi-decennial timescales?

The strategies adopted to answer these questions are often integrated approaches on experimental catchments, where hydrological and biogeochemical studies can be coupled. Acquiring simultaneously time series of climate, hydrology and geochemical data over decades on river systems (both small experimental watersheds and larger basins) representative of the diversity of ecosystems is pivotal for the understanding of these processes, building integrated modeling and for proposing predictive scenarios. Even though currently many CZOs (www.czen.org) are operating globally, very few were set up in the tropics despite the huge importance of these regions in terms of population density, fastchanging land use, biodiversity hotspots, biomass stock on continents (humid forests), size of river systems, etc. In addition, rainfall in the tropics is mostly

\footnotetext{
*Author for Correspondence: E-mail: sekhar.muddu@gmail.com
} 
governed by monsoon systems, which are fluctuating periodically but are also thought to be particularly sensitive to climate change. Vimal Singh (2015) presents the need for such CZO studies from India perspective.

\section{The Kabini Critical Zone Observatory}

The Kabini basin $\left(7000 \mathrm{~km}^{2}\right.$; Fig. 1) spans over a unique climate and morpho-pedologic gradient defined by three zones (humid, semi-arid, transition). The subhumid zone being particularly sensitive to monsoon variability at all timescales, it is particularly interesting for studying the relative influence of climate variability and agriculture on the water and biogeochemical cycles in Southern India. The Kabini CZO aims to provide the unique decennial time series of climatic, hydrological and geochemical variables in the Kabini basin and in some of its nested sub-watersheds. Two Experimental Watersheds (EWS), Mule Hole (forested; $4.3 \mathrm{~km}^{2}$ ) located in the sub-humid zone and Berambadi (cultivated; $84 \mathrm{~km}^{2}$ ) located in the semiarid zone, are monitored since 2003 and 2008, respectively.

The specific objectives of the Kabini CZO are (a) determining the fluxes of water, of inorganic and organic matter present in solution (major anions and cations, carbon and silica) and in suspension (particulate organic carbon); (b) proposing budgets of chemical weathering and physical erosion; and (c) evaluating the impact of agriculture on the above parameters. Its strengths are (i) multiscale approach of nested watersheds, from small experimental watersheds to river basin, and (ii) multidisciplinary approach, currently involving hydrology, geochemistry, soil science, agronomy, remote sensing and ecology. Both the instrumented watersheds of Kabini CZO comprise of the same type of soils and geology except they vary in terms of land use. Mule Hole EWS is located inside the pristine Bandipur National Park and its small size is ideally suited for characterizing soil and subsurface in addition to determining the water and elemental fluxes under undisturbed conditions. The adjacent Berambadi EWS on the contrary is cultivated and strongly influenced by human effects and is a more suitable scale to study the impact of agriculture on water and biogeochemical cycles (nutrients), and to combine land use practices/changes with remote sensed data.

\section{Mule Hole EWS}

\section{Characterization}

The initial phase was dedicated to the physical characterization of the environment and implementation of borewells, weir, instruments and initiation of the hydro-geochemical monitoring. The main soil types, Ferralsol and Vertisol, were identified through pedological survey and then precisely mapped using electromagnetic (EM31) survey (Barbiero et al 2007). Soil transformations through ferrolysis in Vertisol and erosion processes were also studied (Barbiero et al 2007; 2010).

Also, combining the $2 \mathrm{D}$ electrical resistivity surveys in the watershed with weathering indices provided an estimation of the mean regolith thickness, $17 \mathrm{~m}$ (15m saprolite $+2 \mathrm{~m}$ soil) (Braun et al 2009). The comparison with the long term erosion rates indicates that about one million years are required to produce such a regolith cover. In the second phase additional themes were studied as shown in Fig. 2.

\section{Hydrological Budgets}

Hydrological monitoring of Mule Hole watershed included an automatic weather station and gauging station at the outlet set up in July 2003 and 13 piezometers drilled in 2003 and 2004. Hydrological, geochemical and meteorological time series are available in open access at http://bvet.obs-mip.fr. Combining this hydrological monitoring with electrical resistivity tomography and magnetic resonance sounding allowed to demonstrate that groundwater behaviour in the valley was driven by local recharge below the steam (Legchenko et al. 2006; Descloitres et al. 2008). Further, geophysical methods were also used to infer soil moisture (Parate et al. 2011). A water balance based on 2003-2006 records, using water table fluctuations and Chloride Mass Balance (CMB) methods, allowed to highlight the importance of this indirect local recharge $\left(30 \pm 15 \mathrm{~mm} \mathrm{y}^{-1}\right)$ compared to the direct one $\left(45 \pm 9 \mathrm{~mm} \mathrm{y}^{-1}\right)$ and proposed that the total evapotranspiration could represent as much as $86 \pm 9 \%$ of the rainfall (Maréchal et al. 2009). Using a dynamic hydrological model (COMFORT, Ruiz et al. 2010) and time series up to 2009 helped to indicate that groundwater reservoir varies according to long term cycles (about 13-15 years) induced by rainfall pattern and water 


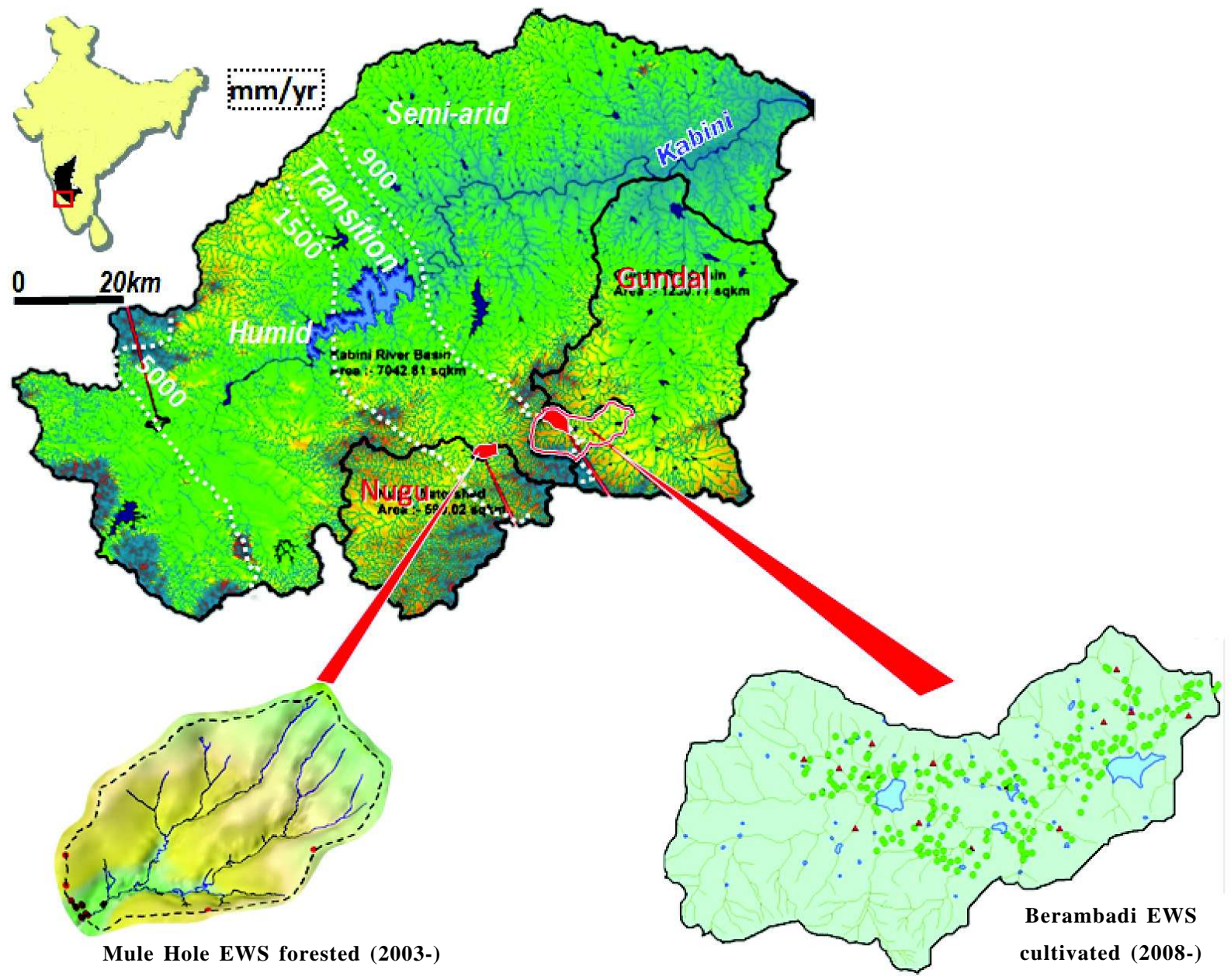

Fig. 1: The Kabini CZO with a pair of monitored EWS of Mule Hole (forested; rainfall: $1100 \mathrm{~mm} / \mathrm{yr})$ and $\mathrm{Berambadi}^{(84} \mathrm{km}^{2}$; rainfall 500-900 $\mathrm{mm} / \mathrm{yr}$ )

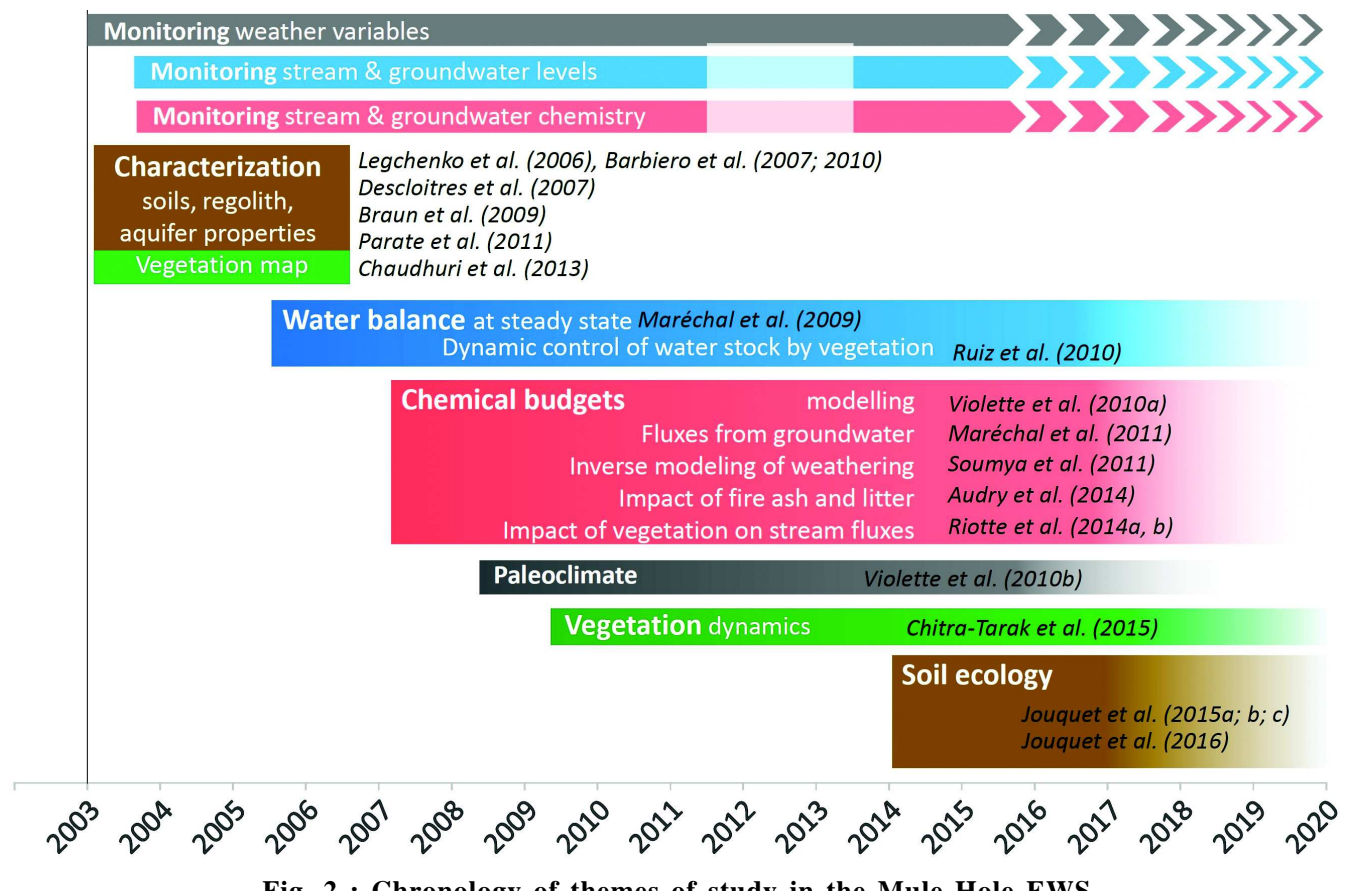

Fig. 2 : Chronology of themes of study in the Mule Hole EWS 
uptake by deep tree roots in the regolith (Fig. 3). For a long time series (1976-2013), the model computed water balance revealed that while stream discharge and groundwater flow account each for about $10 \%$ of the rainfall, with large variations from year to year. Long term evapotranspiration was found to be $78 \%$ of the rainfall. The slight difference with the estimation by CMB method based on the period 2003-2006 was explained by the large increase in water storage in the deep regolith during the monitoring period (12\%, about $\left.145 \mathrm{~mm} \mathrm{y}^{-1}\right)$. For an average rainfall of 1096 $\mathrm{mm}$ (1976-2013) the evapotranspiration was $853 \mathrm{~mm}$ (78\%), stream discharge was $100 \mathrm{~mm}(9 \%)$, groundwater discharge $88 \mathrm{~mm}(8 \%)$ and storage change was $54 \mathrm{~mm}(5 \%)$. Further, studies on the uncertainty in the groundwater discharge leaving the watershed were attempted combining stochastic models of groundwater flow with the geophysical investigations (Chaudhuri et al 2013).

\section{Chemical Budget}

The chemical composition was characterized for fresh rocks, regolith, soils and vegetation and monitored on the long term for water (rainfall, throughfall, soil pore water, seepage, stream, groundwater). This allowed to determine the weathering fluxes in the catchment (Siva Soumya et al., 2009) and by combining an hydrological model with a water-rock interaction model (WITCH) the possible role of secondary phases (smectites) in the silicate weathering (Violette et al. 2010a). Moreover, it revealed that groundwater is the main pathway for element export (Maréchal et al., 2011). Decomposition of flood hydrographs from hydrochemical data (End-Member Mixing Analysis)

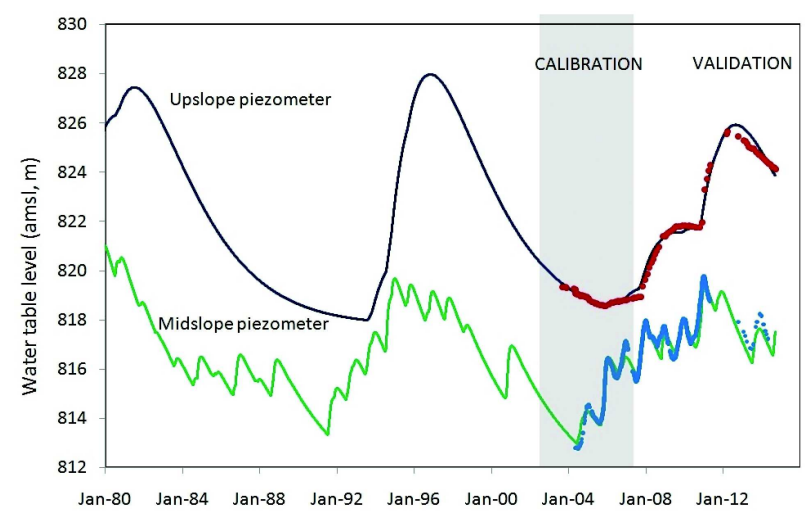

Fig. 3: Observed (dots) and simulated (lines) water table levels of two piezometers in Mule Hole for 1976-2013 along with solute mass balance at soil-plant scale indicated that $\sim 90 \%$ of the fluxes of $\mathrm{Ca}, \mathrm{Mg}, \mathrm{K}, \mathrm{Si}$, Alkalinity exported by the stream have transited through the vegetation. The solute mass balance at soil-plant scale also revealed recycling of nutrients within the watershed, which represents 10 to 20 times the fluxes exported by the stream (Riotte et al. 2014a $\&$ b). Vegetation also controls indirectly, through the water budget, the decennial export of elements that are not taking part in the plant cycle, like $\mathrm{Na}$ (Riotte et al. 2014b). Forest fires enhance the short term mobility and the export of the nutrients (e.g. K) located in leachable ash components compared to the seasonal litter decay (Audry et al., 2014). All these studies indicate that modelling the response of water and biogeochemical cycles to climate change would first require understanding the controls and feedbacks of vegetation on these cycles. This is particularly important in the sub-humid zone of this rainfall gradient, which experienced several episodes of semi-arid conditions since the Last Galcial Maximum (Violette et al. 2010b).

\section{Soil Ecology}

In Mule Hole, soil bioturbation is mainly carried out by fungus-growing termites that are producing soil sheeting (i.e soil aggregates covering the litter consumed by termites, Jouquet et al. (2015a) and cathedral or lenticular above-ground mounds (Jouquet et al., 2015b). If soil sheetings are difficult to observe, termite mounds are clearly conspicuous features of the watershed. They are characterized by specific soil physical and chemical properties and they can be considered patches or highlands of fertility in the watershed (Jouquet et al., 2015c). Soil aggregates from termite mounds are less resistant to the rain than the surrounding soil aggregates, suggesting a lower protection of soil organic matter and a significant contribution of these constructions to erosion (Jouquet et al., 2015c; 2016). However, how do termite mounds contribute to soil renewal and/or erosion at the watershed scale remain unknown. To answer to this question, a monitoring of the 'demography' of about 650 termite mounds (i.e. evolution in size, degradation by predators, new mounds) was initiated 2014. Undoubtedly this unique dataset will help to understand how soil biodiversity responds to the fluctuation of the rainfall pattern, the dynamic of termite mounds, and how they influence soil erosion/ renewal and nutrient cycling. 


\section{Berambadi EWS}

Berambadi experimental watershed $\left(\sim 80 \mathrm{Km}^{2}\right)$ is located in Chamarajanagar district of Karnataka in India (Tomer et al., 2015). This predominantly agricultural watershed is close to the forested Mulehole experimental watershed. The role of this watershed in Kabini CZO was to characterize and capture human processes especially on the hydrology and energy budgets and hence a relatively larger catchment size was selected. However, due to the larger size novel monitoring approaches based on remote sensing were used to retrieve soil moisture, evapotranspiration and soil hydraulic properties. Moreover, instead of dedicated piezometers for groundwater levels, a large number of groundwater wells drilled by the people (mainly farmers) for agricultural purposes were used as sensors for groundwater level observations (Fig. 4). The same approach was also used for water quality studies mainly the nitrates in groundwater with high spatial density of data in the watershed.

Granitic gneiss is the main geology of the Berambadi watershed and is similar to the fractured hard rock system forming most of the Peninsular India. The soil types in the watershed are black, red and rocky/weathered soils, as identified by the geophysical studies (Barbiero et al., 2007). The area is mainly agricultural land with three main cropping seasons, known as Kharif (monsoon, June to September), Rabi (October to December) and summer (January to May) crops. The part of the watershed also has some forest covered areas (Bandipur National park) towards the state border. Major crops in the watershed are turmeric, maize, marigold, sunflower, sorghum, banana and vegetables. The study area lies in a semi-arid climate zone having an approximate mean annual rainfall of $800 \mathrm{~mm}$. Based on the revised Köppen-Geiger climate classification, the study area is classified as AW (Tropical wet and dry or savanna climate). A few salient studies performed in the Berambadi experimental watershed are reported below.

\section{Groundwater Modeling and Budget}

The groundwater levels are monitored in the wells ( 200 numbers) of the farmers at a monthly frequency since May 2010 in the Berambadi watershed. Care is taken to obtain the groundwater levels unaffected by pumping using the knowledge of the electricity provided to these wells, which is often 3-4 hours/day. Fig. 5 presents the trends of

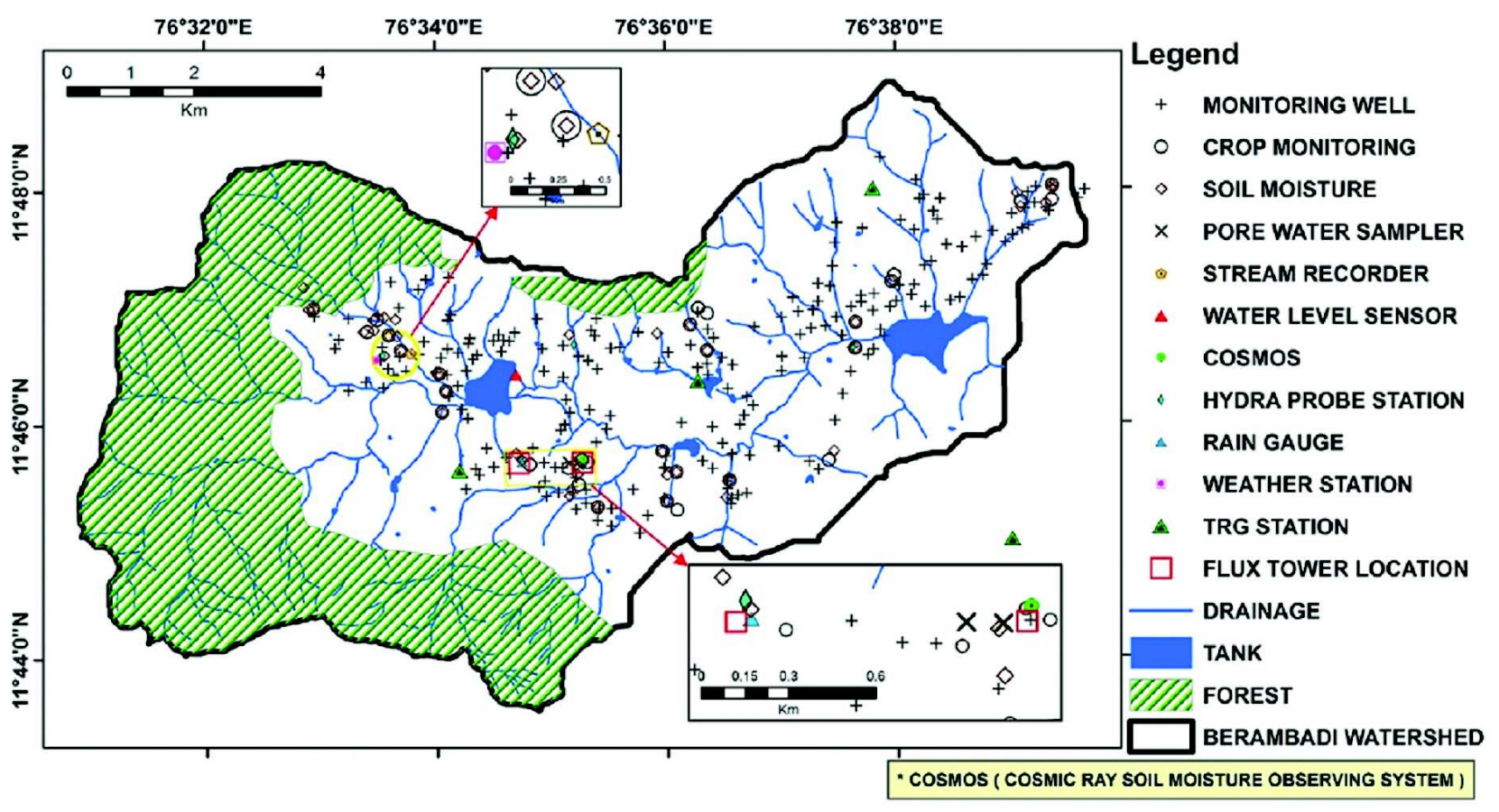

Fig. 4: Berambadi instrumented watershed 

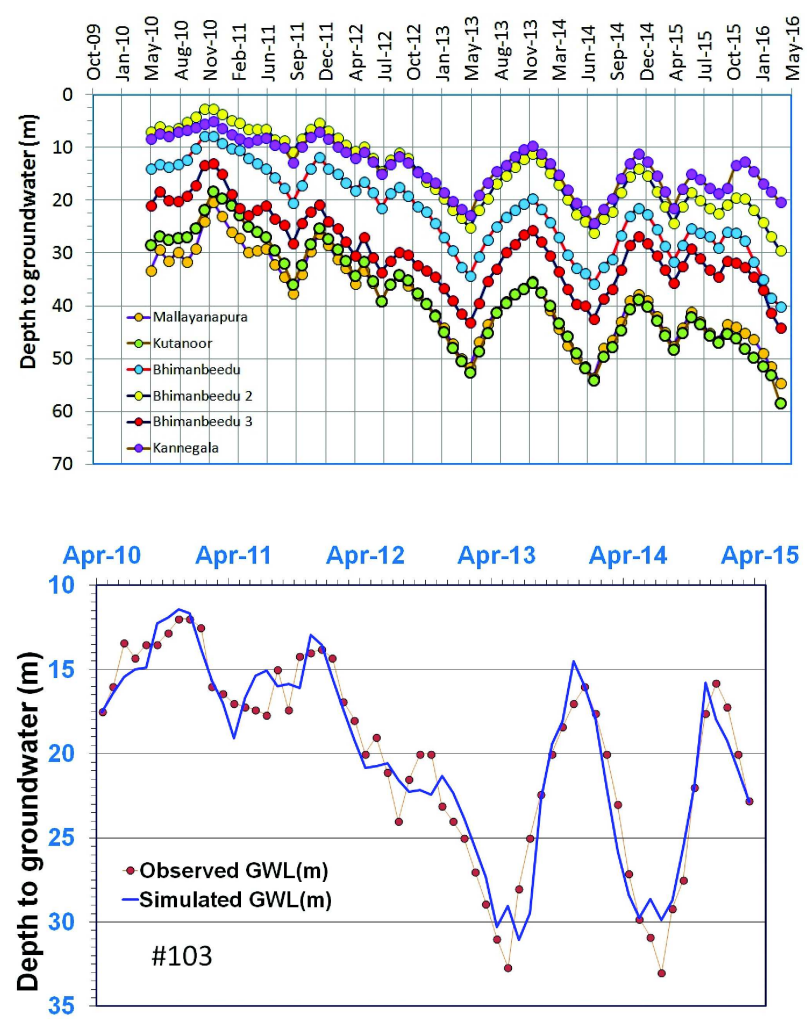

Fig. 5: Measured groundwater level patterns aggregated in various villages of Berambadi. Also presented is the model fit of groundwater levels for a typical well in Honnegowdanahalli village

groundwater levels aggregated from wells in various villages of the watershed.

Using a groundwater model (AMBHAS-GW) developed and tested (de Bruin et al 2012; Subash et $a l ., 2016)$ was used to simulate the groundwater levels and Fig. 5(b) presents the model fit to one typical observation well data. Fig. 6 presents the annual rainfall for 2010-11 to 2014-15 and the mean annual recharge factors (which also includes the return flow from groundwater use). The mean annual recharge across the years was $65 \pm 20 \mathrm{~mm}$. The mean annual groundwater discharge estimate was $50 \pm 10 \mathrm{~mm}$ while the annual mean pumping averaged over the village estimated was $25 \pm 5 \mathrm{~mm}$.

\section{Retrieval of Soil Moisture from Microwave Remote Sensing}

Satellite based active and passive L-band observations acquired by Aquarius are available from September 2011 to June 2015. Using Aquarius data (which was available at $80 \mathrm{~km}$ resolution and temporal resolution
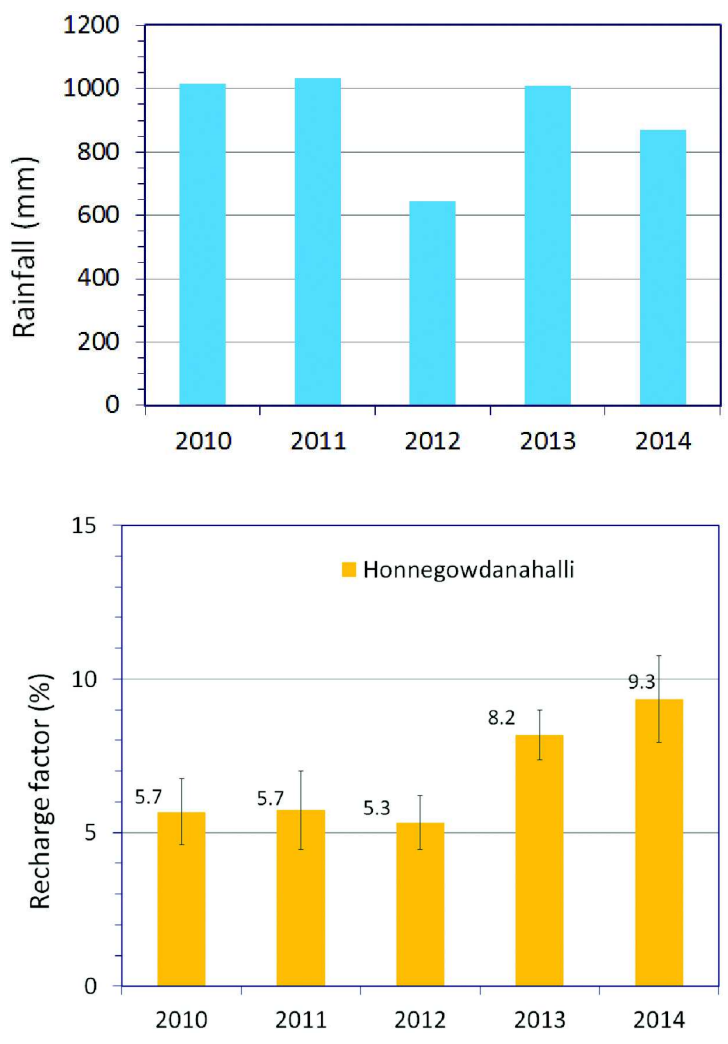

Fig. 6: Annual rainfall (mean annual rainfall for the 5 year period is $915 \mathrm{~mm}$ ) and groundwater recharge factors modeled for case illustrated in Figure 5

of 7 days) investigations were performed by comparing the soil moisture product derived from this satellite with theta probe soil moisture data collected with good spatial coverage over the period of three years in Berambadi experimental watershed of Kabini CZO. The "radar-only" algorithm that was developed (Parag et al., 2015) to account for vegetation and roughness effects, respectively, was used on Aquarius/ SAC-D L-band backscatter observations for estimating the soil moisture. Fig. 7 shows the time series of calibrated Aquarius soil moisture product and its comparison with SMOS soil moisture product (Parag et al. In review).

Passive microwave sensors (e.g SMOS, SMAP) are capable of providing surface soil moisture globally under all weather conditions. However, these have a relatively coarser spatial resolution and cannot meet the requirements of higher resolution applicable for small watersheds. On the other hand, active microwave sensors (e.g RADARSAT-2, RISAT-1) can provide higher resolution (e.g 10-100 meters) 




Fig. 7: Time series of soil moisture from radar-only (calibrated), SMOS and theta probe ground observations at Berambadi watershed
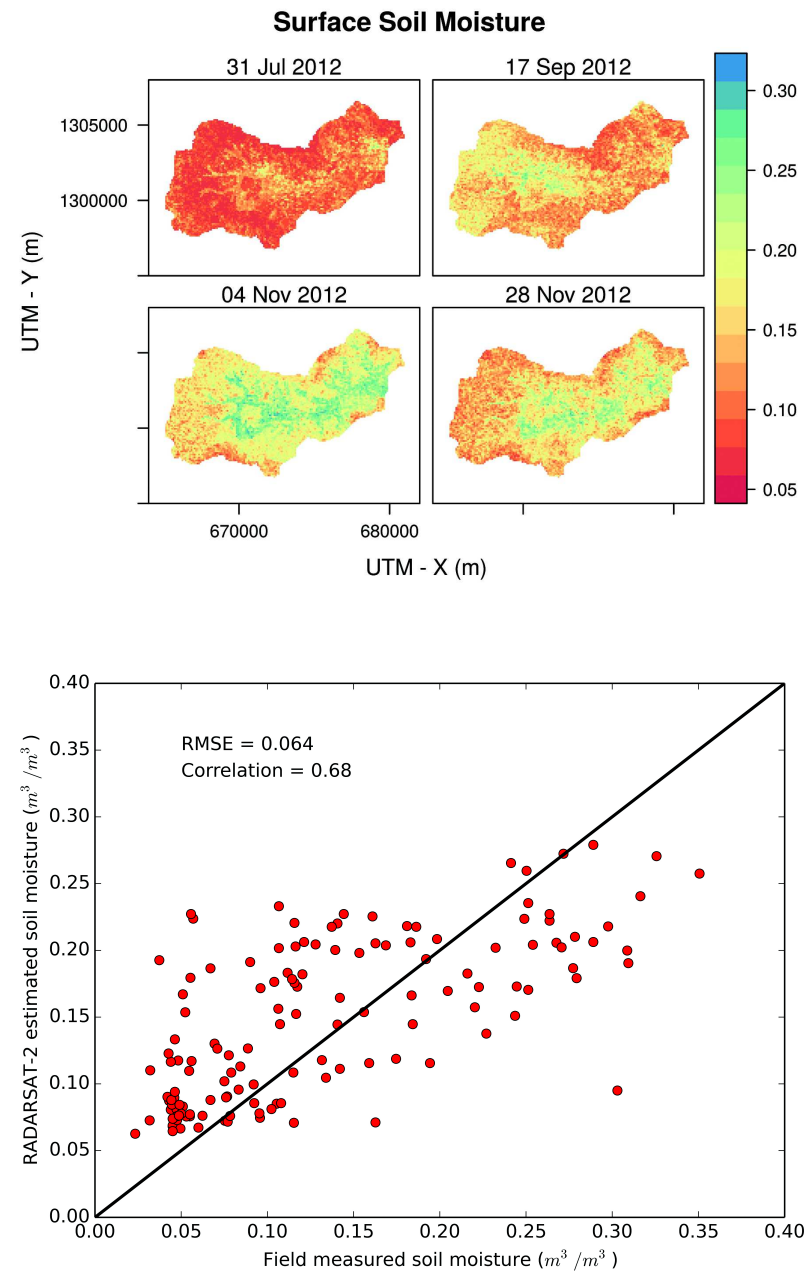

Fig. 8: Surface soil moisture retrieved in Berambadi watershed using RADASAT-2. A comparison of soil moisture estimated with ground measurements is also shown soil moisture with a relatively coarse temporal resolution of 2-4 weeks. Retrieval of soil moisture from active microwave is often relatively complicated since the satellite measured backscattering coefficient is sensitive to the surface roughness and vegetation canopy structure. In the literature, several physically based, empirical and semi-empirical models have been developed to retrieve soil moisture from active microwave sensors. A methodology was developed (Tomer et al., 2015) to retrieve surface soil moisture from active microwave sensors using an approach, which required a set of several backscatter images over time and a soil map (typically available in India from National Bureau of Land Use \& Land Cover Planning) with the soil parameters of wilting point and field capacity. This approach requiring no parameter calibration was validated to retrieve surface soil

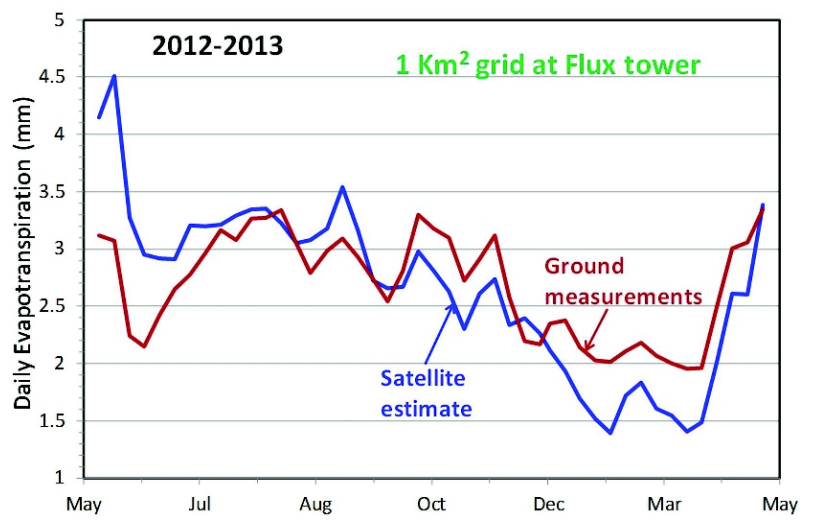

Fig. 9: Comparison of satellite estimated evapotranspiration with ground measurements in Berambadi watershed 


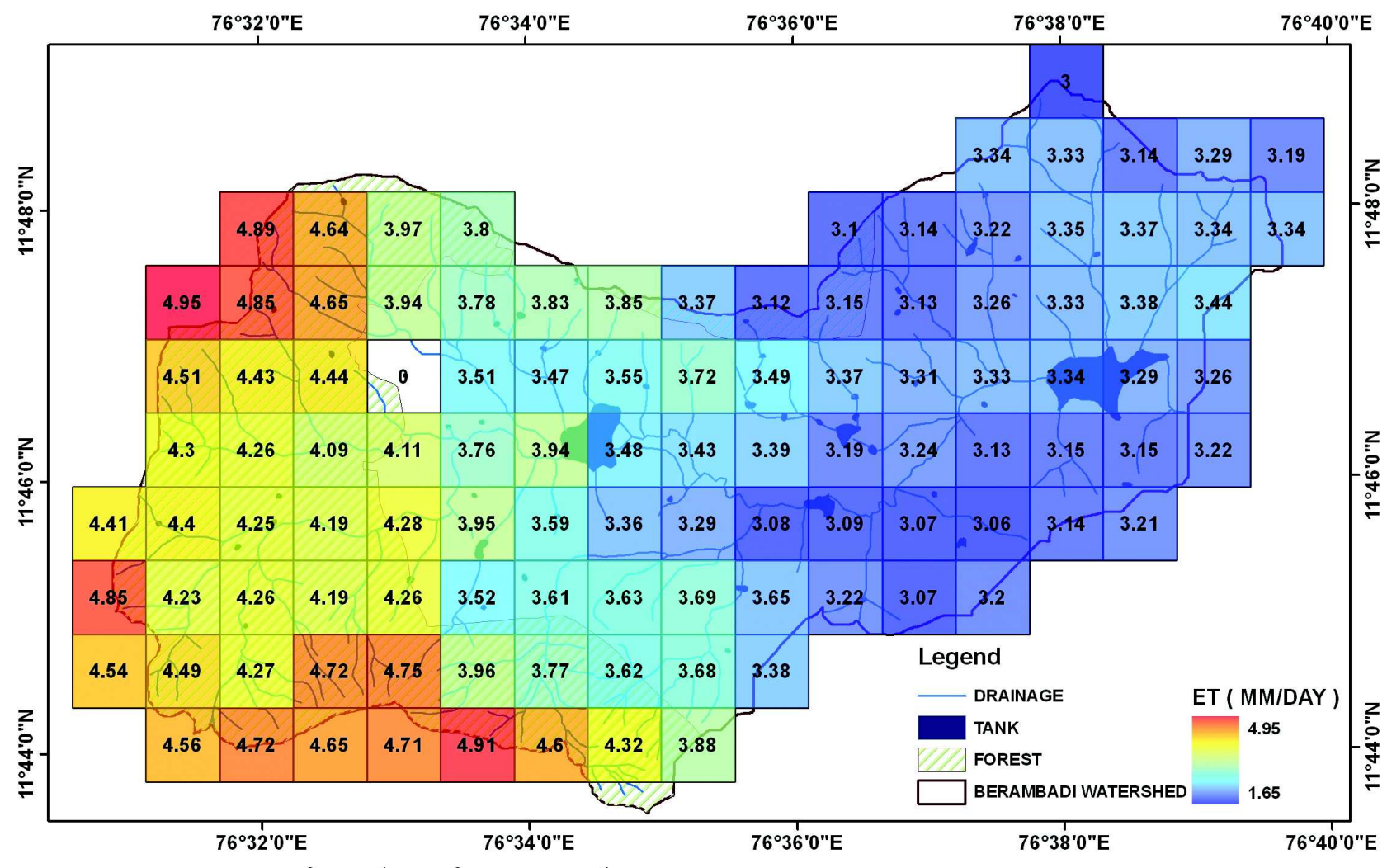

KHARIF 2012

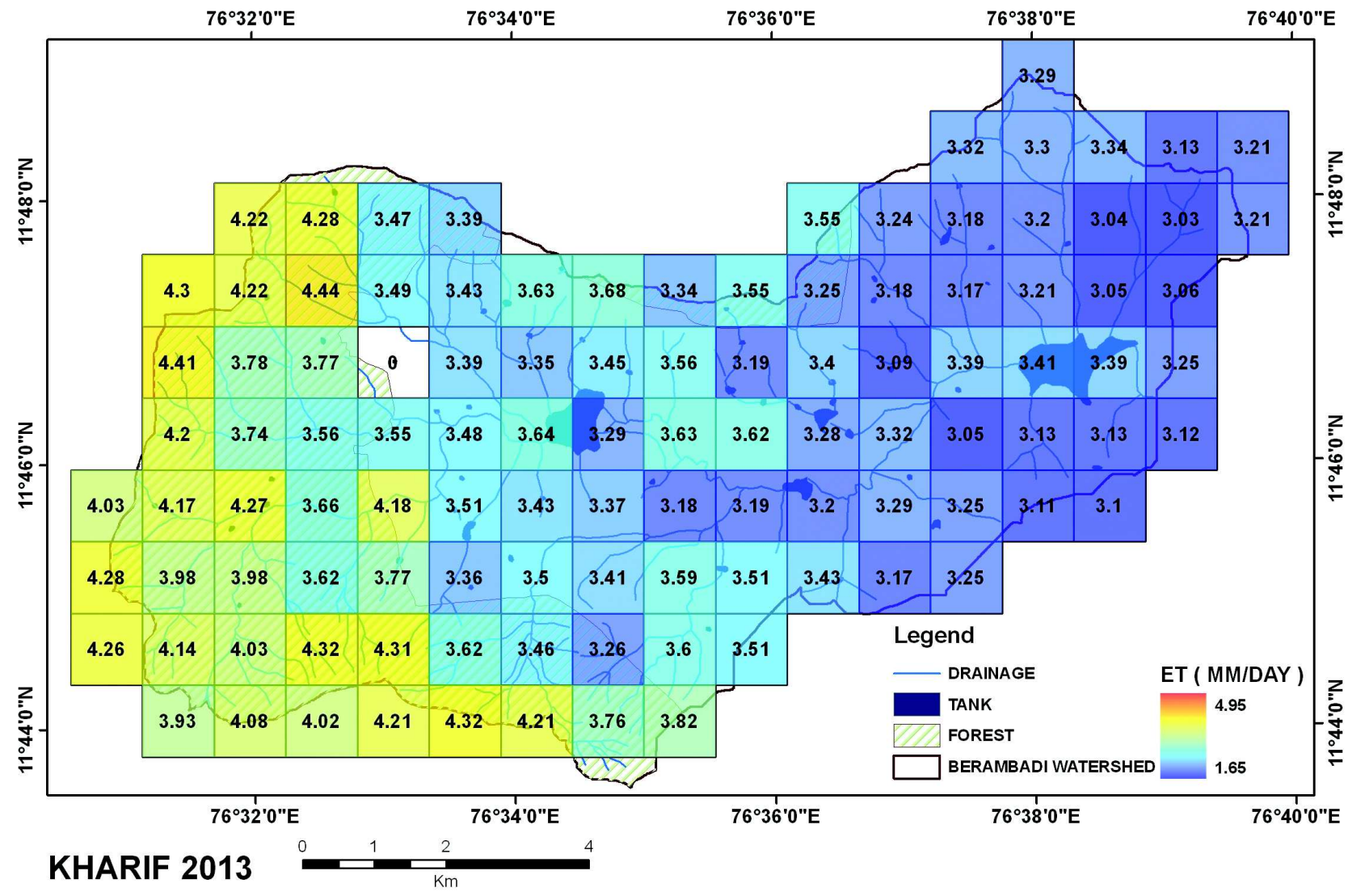

Fig. 10: Mean daily evapotranspiration for (May-September) estimated from satellite 
moisture using field data collected during 30 campaigns (concurrently with RADARSAT-2 overpass) in 50 monitored field plots over a span of four years (20092013) in Berambadi watershed. The mean RMSE was found to be around $0.04-0.06 \mathrm{~m}^{3} / \mathrm{m}^{3}$ and it was assessed that improved performance and reduced bias would be feasible with a high resolution soil map. Figure 8 presents the surface soil moisture retrieved at the spatial resolution of 1 hectare for the four different times during 2012 (a drought year) in Berambadi watershed along with a scatter plot comparing the retrieved and ground measured soil moisture in these dates.

\section{Evapotranspiration Estimation Using Remote Sensing Based Models}

Latent Heat Flux (LHF) or evapotranspiration is a critical component of the hydrologic and energy cycles but repeated and consistent estimation of LHF from ground measurements at regional and other larger scales is difficult due to its spatial and temporal variability. Remote Sensing is the only viable option to map LHF of relatively large areas periodically, in a globally consistent and economically feasible manner. Remote sensing based models that are available for the estimation of LHF can either be complex fully physically based land surface schemes or simple empirical models, which are shown to work with reasonable accuracy for data scarce conditions (Jiang and Islam, 1999). Remote sensing provides only a snapshot of the LHF at the instant of image acquisition whereas it is the temporal average (daily/weekly etc.), which is of real interest to various users. This conversion is often carried out in various models using evaporative fraction. Studies were performed to compare different simple empirical models to estimate LHF using remote sensed data (Eswar et al., 2013, 2016). To compare the evapotranspiration estimated from remote sensing, a micrometeorological tower of $10 \mathrm{~m}$ height developed by the Space Applications Centre of the Indian Space Research Organisation was installed in the Berambadi watershed. Fig. 9 presents evapotranspiration estimated using remote sensing and that from the ground measurements for the 2012-13. The intra-year trends are captured resonably with the simple empirical models develped. Using this approach, a evapotranspiration product (2002-2013) is developed with a spatial resolution of $1 \mathrm{Km}^{2}$ and a temporal resolution of 1 week for the
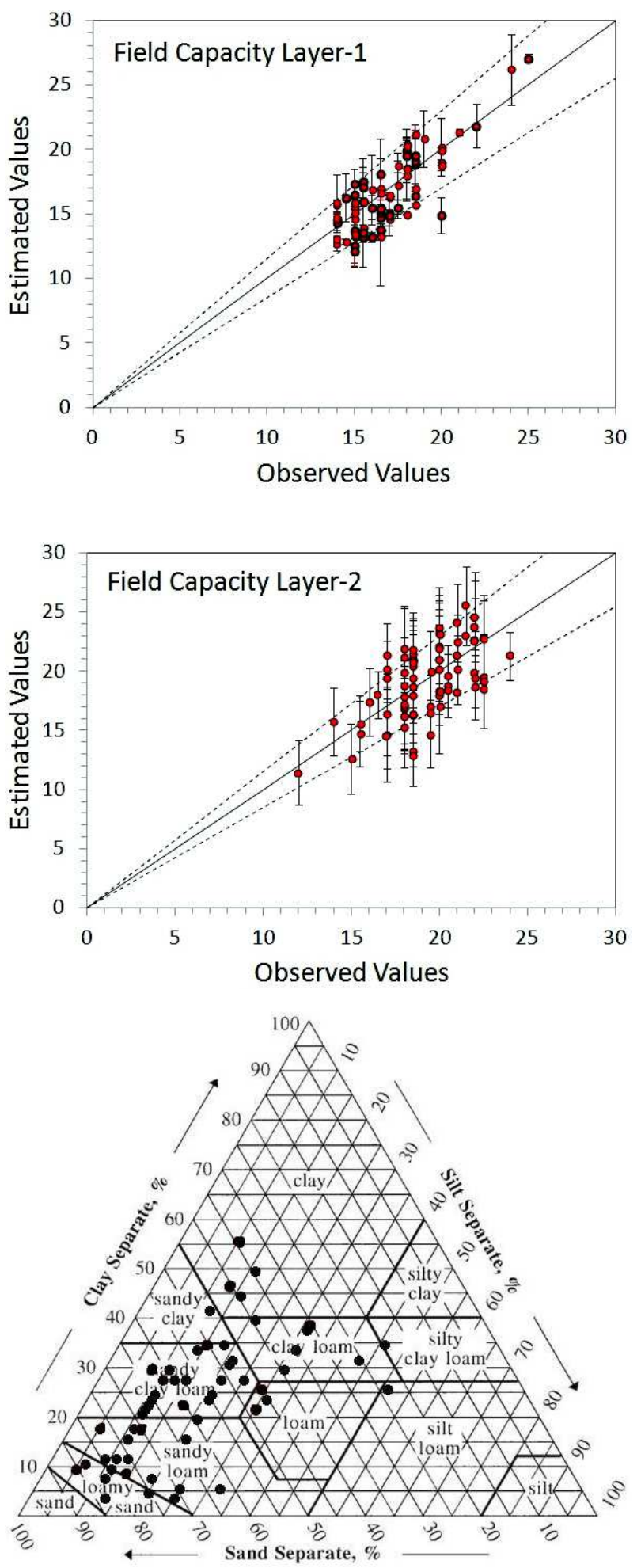

Fig. 11: Estimated field capacity of the two soil horizons in the Berambadi watershed using STICS crop model inversion. Soil properties of the plots used for the validation are also shown

Kabini river basin. Typical spatial patterns of mean evapotranspiration per day for the extended Kharif 

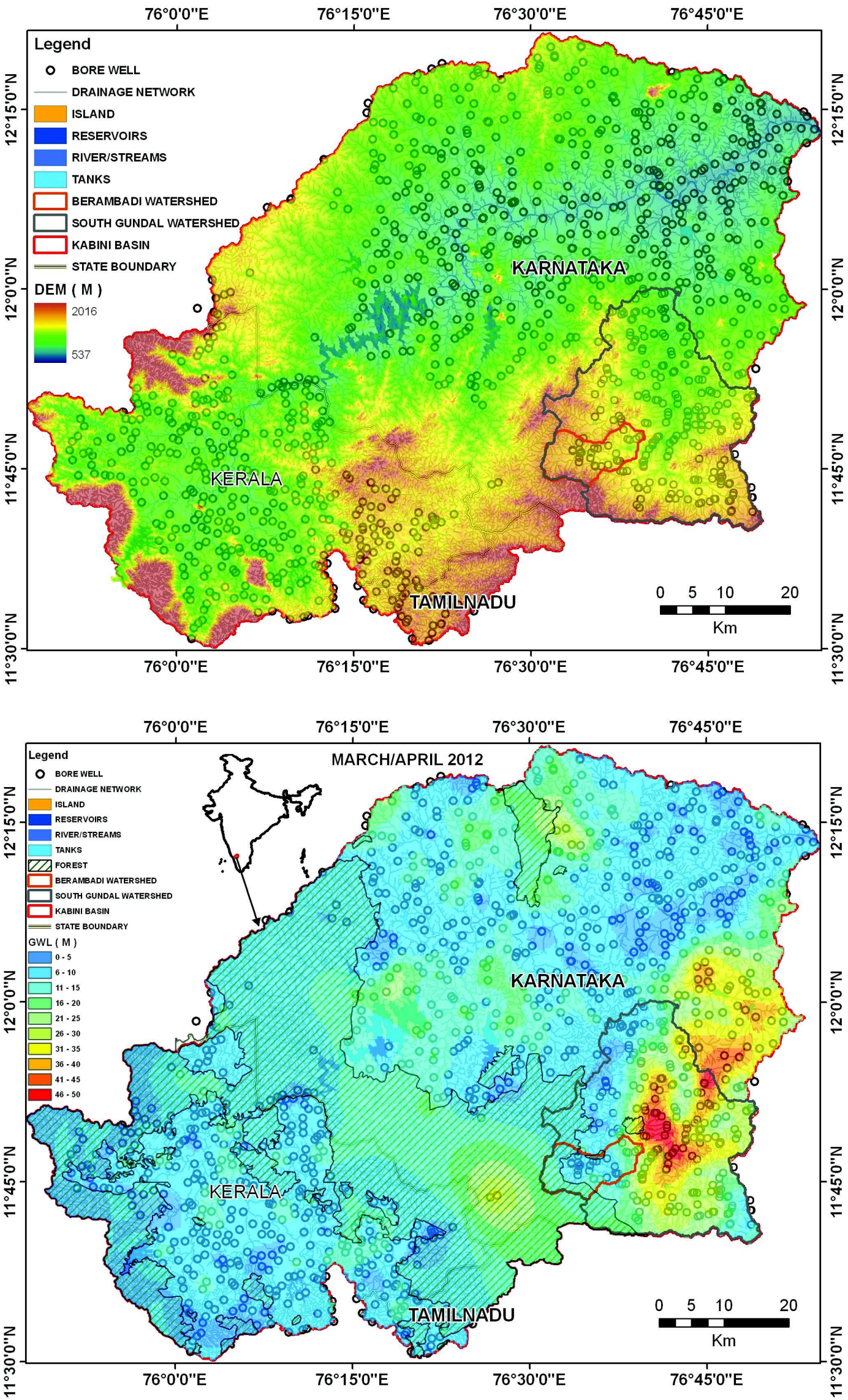


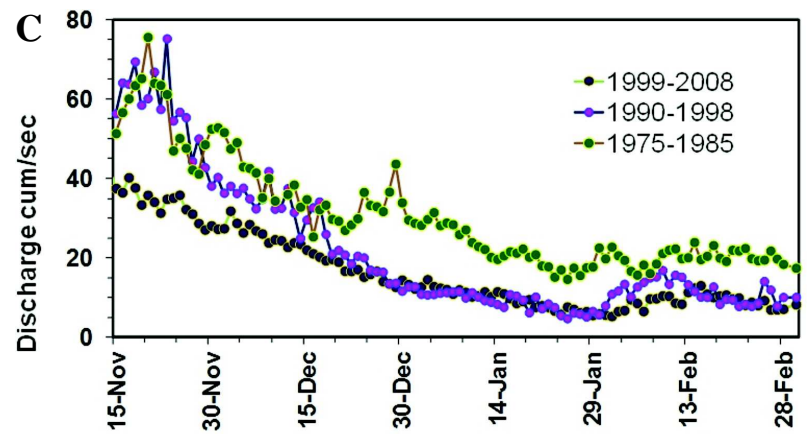

Fig. 12: Kabini basin with the network of observations wells presenting groundwater depeleted regions in the semi-arid part. Also shown are the trends of base flow reductions (as measured at the Kabini dam) over the decades from the humid/transition climatic region

season (May-Sep) in Berambadi watershed is shown for 2012 and 2013 in Fig. 10.

\section{Retrieval of Soil Hydraulic Properties (SHPs) from Remote Sensing}

Available water capacity of soil, which is the difference between the soil water content at field capacity and wilting point is a key parameter for modelling soil water balance and for monitoring soil water content to adjust irrigation. This parameter is one of the most important factor influencing the carbon and nitrogen cycling and the rate of photosynthesis and crop growth. Commonly, at plot scale studies this is determined from tedious laboratory experiments, however, for estimating over larger spatial scales, pedotransfer functions (PTFs) describing the relationship between SHPs and textural characteristics of the soil (which are easily available from soil maps), are often used (Vereecken et al., 1989). One of the alternative approaches that was attempted in the literature for estmating SHPs was through model inversion and remote sensing (Ines and Mohanty, 2008; Montzka et al., 2011). Sreelash et al. (2012, 2013) validated a similar inverse approach hypothesising crop as sensor to estimate available water capacity in the deeper soil horizons of two-layered soils in Berambadi watershed. STICS crop model was used for estimating SHPs and the uncertainity in the estimates was evaluated for different crop types and water regimes and also extended the applicability of the method in Berambadi by combining with leaf area index retrieved using active microwave remote sensed data from RADARSAT-2 (Sreelash et al. in review). Fig. 11 presents the field capacity estimated for the two layers with uncertainty estimated obtained from GLUE in the Berambadi watershed using STICS model inversion and LAI retrieved from RADARSAT2.

\section{Kabini Basin}

The Kabini river basin in south-western India is unique for hydrology because of its exceptional climatic gradient with the mean annual rainfall from west to east characterizing the unique humid, transition and semi-arid zones in the basin. Using an extensive network of groundwater well network (Fig. 12A,B), the groundwater levels were mapped in the basin. In the souther-eastern semi-arid region, the groundwater levels display a pattern that is non-classical hydrogeologically, the valley regions having deeper groundwater levels than the topographically higher zones. This pattern resulted from intensive groundwater pumping in the villages in the valley that started in the early 1990s (Sekhar et al., 2011). The decline in the groundwater level caused the disconnection between the groundwater and the river bed, and the main permanent rivers turned into ephemeral streams (Ruiz et al., 2015). Fig. 12C presents the trends of base flow for the humid and transition region in the Kabini river over the three decades and clearly the base flow appears to be affected by the climatic and land use changes in the humid region and in turn effecting the stream system and indicating the impacts translated from the aquifer to the stream system.

The question that naturally arises is what best land practice should be recommended for this basin specifically, and the region in general, so as to minimise environmental degradation in the long run, while ensuring minimal disruption to the water users of the region. An additional question that arises is how climate change will compound water availability, and how its effects can be best segregated from the anthropogenic impact of the ever-increasing pumping the region has witnessed. 


\section{Acknowledgements}

The studies reported here for Kabini CZO were carried out by several researchers, research scholars and project staff from both India and France and all

\section{References}

Audry S, Akerman A, Riotte J, Oliva P, Maréchal J C, Fraysse F, Pokrovsky O and Braun J J (2014) Contribution of forest fire ash and plant litter decay on stream dissolved composition in a sub-humid tropical watershed (Mule Hole, Southern India) Chem Geol 372 144-161

Banwart S A, Chorover J, Gaillardet J, Sparks D, White T, Anderson S, Aufdenkampe A, Bernasconi S, Brantley S L, Chadwick O, Dietrich W E, Duffy C, Goldhaber M, Lehnert K, Nikolaidis N P and Ragnarsdottir K V (2013) Sustaining Earth's Critical Zone(http://www.czen.org/sites/default/ files/Sustaining-Earths-Critical-Zone_FINAL290713.pdf)

Barbiero L, Parate H R, Descloitres M, Bost A, Furian S, Mohan Kumar M S, Kumar C, Braun J J (2007) Using a structural approach to identify relationships between soil and erosion in a semi-humid forested area, South India CATENA 70 313-329

Barbiero L, Mohan Kumar M S, Violette A, Oliva P, Braun J J, Kumar C, Furian S, Babic M, Riotte J and Valles V (2010) Soil transformations through ferrolysis induced by recent natural drainage in Vertisols of 1 sub-humid South India Geoderma 156 173-188

Braun J J, Descloitres M, Riotte J, Fleury S, Barbiero L, Boeglin J L, Violette A, Lacarce E, Ruiz L, Sekhar M, Kumar M S M, Subramanian S and Dupre B (2009) Regolith mass balance inferred from combined mineralogical, geochemical and geophysical studies: Mule Hole gneissic watershed, South India Geochimica and Cosmochmica Acta 73935961

Chaudhuri A, Sekhar M, Descloitres M, Godderis Y and Braun J J (2013) Constraining complex aquifer geometry with geophysics (2D ERT and MRS measurements) for stochastic modeling of groundwater flow Jour Applied Geophysics 98 288-297

de Bruin A, de Condappa D, Mikhail M, Tomer S K, Sekhar M and Barron J (2012) Simulated water resource impacts and livelihood implications of stakeholder developed scenarios in the Jaldhaka basin India Water International 37 492-508 of them are sincerely acknowledged. Funding from various agencies and permission by the Karnataka Forest Department for the above studies is acknowledged.

Descloitres M, Ruiz L, Sekhar M, Legchenko A, Braun J J, Kumar M S M and Subramanian S (2008) Characterization of seasonal local recharge using electrical resistivity tomography and magnetic resonance sounding Hydrological Processes 22 384-394

Eswar R, Sekhar M and Bhattacharya B K (2013) A simple model for spatial disaggregation of evaporative fractionComparative study with thermal sharpened land surface temperature data over India Journal of Geophysical Research - Atmospheres 118 029-044

Eswar R, Sekhar M and Bhattacharya B K (2016) Disaggregation of LST over India: Comparative analysis of different vegetation indices International Journal of Remote Sensing (In Press) (http://dx.doi.org/10.1080/01431161.2016. 1145363)

Ines A V M and Mohanty B P (2008) Near-surface soil moisture assimilation for quantifying effective soil hydraulic properties under different hydro-climatic conditions Vadose Zone J 7 39-52 (doi: 10.2136/vzj2007.0048)

Jouquet P, Guilleux N, Caner L, Chintakunta S, Ameline M and Shanbhag R (2015a) Influence of soil pedological properties on termite mound stability Geoderma $\mathbf{2 6 2}$ 45-51

Jouquet P, Guilleux N, Shanbhag R R and Subramanian S (2015b) Influence of soil type on the properties of termite mound nests in Southern India Applied Soil Ecology 96 282-287

Jouquet P, Guilleux N, Chintakunta, S, Mendez M and Shanbhag R R (2015c) The influence of termites on soil sheeting properties varies depending on the materials on which they feed Eur J Soil Biol 69 74-78

Jouquet P, Chintakunta S, Bottinelli N, Subramanian S and Caner L (2016) The influence of termites on soil macro- and micro-aggregates varies with soil properties Applied Soil Ecology 101 117-123

Jiang L and S Islam (1999) A methodology for estimation of surface evapotranspiration over large areas using remote sensing observations Geophysical Research Letters 26 2773-2776

Legchenko A, Descloitres, M, Bost A, Ruiz L, Reddy M, Girard 
J F, Sekhar M, Mohan Kumar M S and Braun J J (2006) Efficiency of Magnetic Resonance Soundings applied to characterization of anisotropic crystalline basement aquifers Groundwater $\mathbf{4 4}$ 547-554

Marechal J C, Varma M R R, Riotte J, Vouillamoz J M, Kumar M S M, Ruiz L, Sekhar M and Braun J J (2009) Indirect and direct recharges in a tropical forested watershed: Mule Hole, India Journal of Hydrology 364 272-284

Marechal J C, Riotte J, Lagane C, Subramanian S, Kumar C, Ruiz L, Audry S, Murari V and Braun J J (2011) Chemical groundwater outputs from a small drainage watershed: Mule Hole, South India Appl Geochem 26 S94-S96

Montzka C, Moradkhani H, Weihermuller L, Franssen H H, Canty M and Vereecken H (2011) Hydraulic parameter estimation by remotely-sensed top soil moisture observations with the particle filter Journal of Hydrology 399 410-421 (doi: 10.1016/j.jhydrol.2011.01.020)

Narvekar P S, Entekhabi D, Kim S and Njoku E (2015) Soil moisture retrievalusing L-band radar observations IEEE Trans Geosci Remote Sensing 533492-3506

Narvekar P S, Sekhar M, Tomer S K, Das N, Entekhabi D and Le Vine D Evaluation of Aquarius radar soil moisture estimates and comparison with radiometer products In review with IEEE Trans Geosci Remote Sensing NRC (2001) National Research Council committee on Basic Research Opportunities in the Earth Sciences, Basic Research Opportunities in the Earth Sciences, National Academies Press, Washington, DC, 2001

Parate H R, Mohan Kumar M S, Descloitres M, Barbiero L, Ruiz L, Braun J J, Sekhar M and Kumar C (2011) Comparison of electrical resistivity by geophysical method and neutron probe logging for soil moisture monitoring in forested watershed Current Science 100 1405-1412

Riotte J, Marechal J C, Audry S, Kumar C, Bedimo J P, Ruiz L, Sekhar M, Varma M R R, Lagane C and Braun J J (2014) Vegetation impact on stream chemical fluxes: Mule Hole watershed (South India) Geochimica and Cosmochmica Acta 145 116-138

Riotte J, Ruiz L, Audry S, Sekhar M, Mohan Kumar M S, Siva Soumya B and Braun J J (2015) Impact of vegetation and decennial rainfall fluctuations on the weathering fluxes exported from a dry tropical forest (Mule Hole) Procedia Earth and Planetary Science 10 34-37

Ruiz L, Murari R R V, Mohan Kumar M S, Sekhar M, Maréchal J C, Descloitres M, Riotte J, Sat Kumar Kumar C and Braun J J (2009) Water balance modelling in a tropical watershed under deciduous forest (Mule Hole, India) :
Regolith matric storage buffers the groundwater recharge process Journal of Hydrology 380460-472

Ruiz L, Sekhar M, Thomas A, Badiger S, Bergez J E, Buis S, Corgne S, Riotte J, Raynal H, Bandyopadhyay S and Gascule C (2015) Adaptation of irrigated agriculture to climate change: trans-disciplinary modelling of a watershed in South India. Hydrological Sciences and Water Security: Past, Present and Future. Proceedings of the 11th Kovacs Colloquium, Paris, France, June 2014. IAHS Publ 366 2015 (doi: 10.5194/piahs-366-137-2015)

Sekhar M, Javeed Y, Bandyopadhyay S, Mangiarotti S and Mazzega P (2011) Groundwater management practices and emerging challenges: Lessons from a case study in the Karnataka State of South India. In: IAHR Monograph on Groundwater Management Practices (eds.) Findkakis A N and K Sato Chapter 5, CRC Press, ISBN 10: 0415619874

Siva Soumya B, Sekhar M, Riotte J, Audry S, Lagane C and Braun J J (2011) Inverse models to analyze the spatiotemporal variations of chemical weathering fluxes in a granito-gneissic watershed: Mule Hole, South India Geoderma 165 12-24

Sreelash K, Sekhar M, Ruiz L, Sat Kumar Guérif M, Buis S, Durand P and Gascuel-Odoux C (2012) Parameter estimation of a two-horizon soil profile by combining crop canopy and surface soil moisture observations using GLUE Journal of Hydrology 456-457 57-67

Sreelash K, Sekhar M, Ruiz L, Buis S and Bandyopadhyay S (2013) Improved modeling of groundwater recharge in agricultural watersheds using a combination of crop model and remote sensing Special Issue of Journal of Indian Institute of Science 93 189-207

Subash Y, Sekhar M, Tomer S K, Sharma A K A framework for assessment of climate change impacts on the groundwater system (In: Sustainable Water Resources Management, Editors: C S P Ojha, S Rao, T Zhang and A Bardossy). Chapter 14, ASCE Book Chapter. (In Press)

Tomer S K, Al Bitar A, Sekhar M, Corgne S, Bandyopadhyay S, Sreelash K, Sharma A K, Zribi M and Kerr Y (2015) Retrieval and multi-scale validation of soil moisture from multi-temporal SAR data in a tropical region Remote Sensing 7 8128-8153

Vereecken H, Maes J, Feyen J and Darius P (1989) Deriving pedotransfer functions of soil hydraulic properties In: ISSS symposium, Wageningen, pp 121-124

Vimal Singh (2015) The Indian critical zone - a case for priority studies Current Science 108 1-2 
Violette A, Goddéris G, Maréchal J M, Riotte J, Oliva P, Mohan Kumar M S, Sekhar M and Braun J J (2010a) Modelling the chemical weathering fluxes at the watershed scale in the Tropics (Mule Hole, South India): Relative contribution of the smectite/kaolinite assemblage versus primary minerals Chem Geol 277 42-60
Violette A, Riotte J, Braun J J, Oliva P, Maréchal J C, Sekhar M, Jeandel C, Subramanian S, Barbiero L and Dupré B (2010b) Formation and preservation of pedogenic carbonates in South India, links with paleomonsoon and pedological conditions: Clues from $\mathrm{Sr}$ isotopes, U-Th series and REEs Geochim Cosmochim Acta 74 7059-7085. 